wcre observed, bnt they were clearly distinguishable by their larger size and by the absence of the zone of peripheral congestion.

Hospital Contagion of Pneumonia.-G. VABIot (Journal de Clinique et de Therapeutigue injantiles, 1898, No. 13, p. 246) reports an apparently clear case of contagion.

Jean M. was ndmitted to the ward and placed in $n$ bed beside thnt of Cbarles S., who was then just entering the acnte stage of cronpous pnenmonia. Jean romained in the bed next to Charles dnring the whole course of the latter's disease, and eleven days after his admissiun, or six days after the defervescence of the disense in his neigb bor, his temperature rose nnd he passed tbrongb an nneventful attack of the same malady.

This observution is by no means nnique, similar cases hnving been recorded by Minot, Netter, nnd Comby. The nuthor suggests that observations of this cbaracter, in whicb the dates are carefully noted, will enable one to determine the period of incnbation of pneumonia. In such cases it is to be presumed that the transmission of germs has not been direct, but that the micro-organisms suspended in tbe dust or adhering to the bed-clothing bave been the means of prodncing the disease. Netter, who bas observed similar instances of contagion nmong adnlts, thinks tbat the direct transmission of germs should be rarer amoog young cbildren, because tbey do not expectorate. It seems certain, bowever, tbat even if the cbild does not expectorate, like the adult, into a vessel, be conghs withont any precaution, and in tho paroxysms of congb must scatter minute portions of the pulmonary secretions upon bis own or neighboring beds. It is nlso quite likely that during the course of the disease in Charles his neigbbor came close to bis bed.

\title{
S URGERY.
}

UNDER THE CHARGE OF

J. WILLIAMI WHTE, M.D.

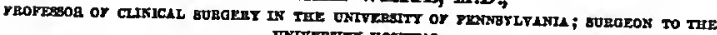
UNIVERATT HOERTAL:

Anesred $\mathrm{Ex}$

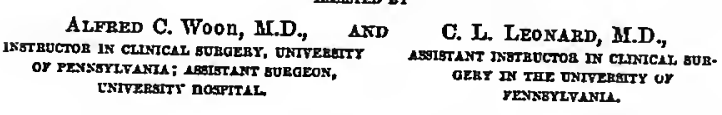

Olinical Remarks on Btricture of the Urethra.-The following classification is one wbich HABRISON (The Lancet, April 23, 1898) uses for clinical purposes: Fingt, those amennble to some form of dilntation; second, those fond to be nnadapted for sucb trentment, and where other measures sbonld - he considered; and tbird, tbose wbich may hnve been regarded as impassable
strictares. 
The first closs includes hy fur the greatest numher ood oll strictures in thcir early stages. When this process of treatment proceeds satisfoctorily, as it usually does, the pgtient is soon nhle to nndertake the management of his own case after he has heen instructed in the use of the approprinte instrument. It is very easy to injnre a stricture ond so lose the way through it. On making on examination of this kind, the ohject shonld he to ascertain, without causing pain or hleeding, if possihle (1) the presence and position of the ohstruction, nnd (2) the degree of contraction which has heen orrived nt.

For this purpose the author prefers long, flexible hongies, twenty incbes in length, which commence in a probe-point and grodually increase in size. They moy be softened hy plocing them in wsrm water hefore use, and become an flexible thot they will coil np in the bladder. Besides their use as exploratory instruments, he employs them to smooth ont a rough urethra and make the occess to a stricture fnnnel-shaped, so that it may he more easily cntered. It is sometimes necessary to use flifórm bongies to detect the entrance through the gtricture. The long hougies ("wbips") are useful in relieving reteotion of urine from a stricture that has contracted. The gradual dilatation produced persists enficiently nfter the witbdrawal of the instrument, so that the patient is able voluntarily to empty his blodder. They are very safe, as no force can he used with them, and the nutbor believes they should he more generally employed.

The second class ore cases that are not adopted to dilstation, as, for instance, tbose following wonnds or injnries of the urethra. The difficulty may nrise from the character of the gear tissue, its contractility, or there mng be certain constitutionnl disturbances following attempts at dilntation of the gentlest kind.

These cases the author relieves by introducing a splice of new tissue into the floor of the stricture by internal urethrotomy, usually by Maisonnenve's instrument As healing tskes place nnder the occasional use of $u$ bongie, $o$ splice is formed of new tissue where the stricture was divided. For fortyeight honrs or so bcfore this is done it is well to sterilize the nrine with some horic acid tnken hy the month, in amall doses, or, as be has found hetter, boracite. The former sometimes produces indigestion, while the latter is hoth pleasant ond reliahle.

The filiform pilot is passed into the bladder, the fine metal director following it. The urethrotome is next run along the groove in the lotter, ond the strictures are divided from before bockword. Care sbould be taken not to run the blade too for bock and injure fibres of the sphincter, or excessive hleeding will he caused. A scries of metal hnlhow hongies (10-15, English gauge) should be passed successively hefore the patient recovers from the onsesthetic. All metal instruments for wse in connection with a strictured urethra should be hnlhous or olive-headed. The blsdder is then emptied of any urine it may contain and washed out with a solution of perchloride of mercury (1:6000) until the lotion runs quite clear. An ounce or go is left hehiod in the blodicr, so thot the first urine voluntarily passed moy he steritized. Carholized vaseline (three grains to two ounces) is used for the instruments. The author rorely ties a catheter in the hladder unless o chronic stricture bas induced an atonic hlodder, when n soft catheter moy he 